\title{
26. STRUCTURAL FEATURES IN CORES FROM THE NANKAI TROUGH, DEEP SEA DRILLING PROJECT LEG 87A ${ }^{1}$
}

\author{
Neil Lundberg, Earth Sciences Board, University of California, Santa Cruz \\ and \\ Daniel E. Karig, Department of Geological Sciences, Cornell University²
}

\begin{abstract}
Small-scale structures in Leg 87A cores provide details on the fold-and-thrust-style deformation produced by subduction at the Nankai Trough. Bedding dips at Holes 583B, 583C, and 583D define a steep homocline interpreted as the seaward limb of hanging-wall anticline formed over a thrust ramp. A thin interval of steep dips between 150 and $160 \mathrm{~m}$ is suggestive of drag along a hanging-wall fault splay. A balanced reconstruction of postulated structure, assuming plane strain, indicates $280 \mathrm{~m}$ of horizontal displacement along the thrust. Quantitatively less important mechanisms of shortening include minor reverse faults, broad open folding, and kink bands. Kinks are dark planar surfaces developed in the cored sediment, along which primary features have been rotated in the sense of a reverse fault. Specifically, kinks are made up of multiple strands that are sharply bounded and regularly arranged domains of strongly aligned phyllosilicates. They are consistently high-angle features, geometrically and kinematically similar to high-angle reverse faults defined seismically in the protothrust zone in front of the thrust belt. We suggest that kinks formed in an analogous setting, when the section penetrated at Site 583 occupied the landward portion of the trench.

A reference section drilled at Site $\mathbf{5 8 2}$ in the trench floor provides a control for structural features at Site 583. Aside from a bedding-parallel fissility, the only structures observed in cores from Site 582 are healed normal faults and vein structure. These are present only in Shikoku Basin hemipelagic mudstones that underlie trench deposits, and probably reflect extension caused by flexure of the Philippine Plate. These structures are not present in cores from Site 583, which did not penetrate through the uplifted trench-fill section.
\end{abstract}

\section{INTRODUCTION}

Subduction zones constitute one of the most complex structural environments. Drilling in forearc regions has revealed a broad spectrum of tectonic styles. Variations of the imbricate thrust model, proposed on the basis of geophysical studies of forearc areas (Karig, 1974; Seely et al., 1974; Karig and Sharman, 1975), explain the principal drilling results along some active margin transects (Moore, Watkins, et al., 1982; Moore, Biju-Duval, et al., 1982), but are inapplicable in others (Hussong and Uyeda, 1982; von Huene, et al., 1980). The ultimate fate of sediments that enter subduction zones ranges from accretion by various mechanisms to subduction, and data from several margins have been interpreted by some workers to suggest tectonic erosion of the forearc by the incoming ocean crust (Schweller and Kulm, 1978; Hussong and Uyeda, 1982).

Studies of modern forearcs provide actual comparison with ancient analogs as well as defining the physical conditions under which various processes operate. By the very nature of the process, most ancient analogs studied on land are accretionary complexes, formed at some variant of accreting margins (see Dickinson and Seely, 1979 for review). They are sediment rich and show a variety of deformational styles, from fold-and-thrust belts containing broad coherent terranes of presumed trench

\footnotetext{
${ }^{1}$ Kagami, H., Karig, D. E., Coulbourn, W. T., et al., Init. Repts. DSDP, 87; Washington (U.S. Govt. Printing Office).

2 Addresses: (Lundberg, present address) Department of Geological and Geophysical Sciences, Princeton University, Princeton, New Jersey 08544; (Karig) Department of Geological Sciences, Cornell University, Ithaca, New York 14853.
}

and trench-slope deposits to stratigraphically chaotic melange terranes (e.g., Cowan, 1974; Smith et al., 1979; Moore and Karig, 1980; Leggett et al., 1982). Structural features are readily observable in ancient accretionary complexes, but deformational processes and physical conditions of deformation must be inferred. These features typically range from syndepositional disruption near the sediment surface through a variety of more brittle processes to complex ductile deformation associated with blueschist metamorphism at depth. Multiple phases and styles of deformation typically overprint one another, and the resulting chaos is difficult at best to unravel.

The nature of processes that deform sediment and rock within accretionary prisms is still poorly known. Outstanding questions concerning structures seen in accretionary complexes include (1) whether the operative processes are driven by gravity or by tectonic forces (Elliott, 1976; Seely, 1977); (2) what the degree of lithification of sediments was during deformation (Hsü, 1974; Cowan, 1978); (3) whether mixing of lithologies is due to surficial sedimentary processes or to some type of deep-seated tectonic process (Maxwell, 1974; Hsü, 1974); and (4) whether the deformation seen is a result of flattening or of simple shear (Cowan, 1978; Draper, 1978; Quinquis et al., 1978). Clearly, knowledge of environmental variables during deformation would be extremely useful in resolving these questions. Although DSDP cores are limited in quantity and locations represented, and sample only the shallowest portions of trench slopes, they nevertheless provide close constraints on the physical conditions and tectonic environments in which structural features have developed at shallow levels. 
The general structural framework of accretionary forearcs is well known from seismic reflection profiles, but many structures in accretionary prisms are too small and too complex to be resolved seismically. Thrust faults have been widely inferred, delineated on reflection profiles, and documented biostratigraphically by age reversals in DSDP cores from the Barbados transect (Moore, BijuDuval, et al., 1982). Scaly mudstones, stratal disruption, vein structure, pervasive fractures, and spaced foliation are developed in sediment cored by DSDP in forearcs (Arthur et al., 1980; Lundberg and Moore, 1982; Cowan, 1982; Dengo, 1982), but these generally cannot be correlated to features of seismic-reflection profiles.

The slope landward of the Nankai Trough is an accretionary forearc with large-scale structures clearly delineated by a superbly processed seismic line (Nasu et al., 1982); here the drilled samples can be located with accuracy within this seismically defined structural framework. In addition, sediment in the Nankai Trough provides favorable drilling conditions; it is sufficiently mud rich to allow stable hole conditions, yet with adequate lithologic variety and consequent impedance contrast to permit seismic definition of structure.

In this report we present macroscopic and microscopic observations of the cores recovered from Sites 582 and 583, drilled in the Nankai Trough and landward slope. Methodology is as reported by Lundberg and Moore (1982). Data on the distribution and orientation of smallscale structures were collected where available from all Leg $87 \mathrm{~A}$ cores, and these data are presented graphically on a structural log. Samples of structural fabrics were impregnated and studied in thin section, and the results of our fabric studies were then integrated with analysis of the larger structures defined by bedding dips in drill cores and by seismic-reflection profiles.

\section{REGIONAL SETTING AND DRILLING RESULTS}

During Leg 87A two sites were drilled in and near the Nankai Trough, off southwestern Japan (Fig. 1). Site

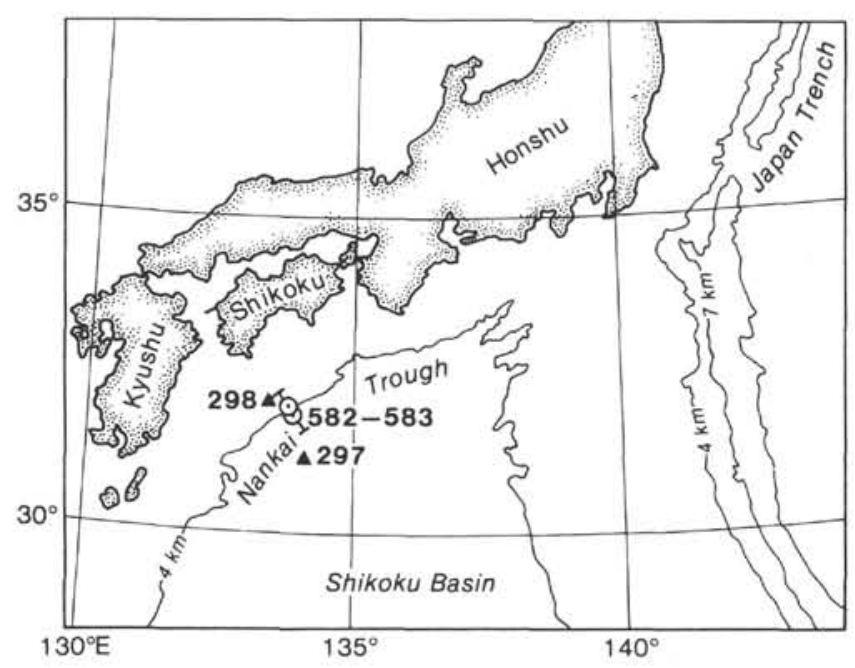

Figure 1. Location of sites drilled on Leg 87A, plus sites drilled near Nankai Trough on Leg 31 . The approximate location of the seismic profile of Figure 2 is indicated.
582 , on the floor of the Nankai Trough itself, provides a seaward reference section for trench-fill deposits (Fig. 2). Hole 582 penetrated through the trench wedge into the underlying Shikoku Basin sediments, which can be correlated with drilling results at Site 297 (Leg 31; Ingle, Karig, et al., 1975) located approximately $100 \mathrm{~km}$ to the south. Site 583 , located on the first structural ridge or terrace up the inner trench slope, was planned to penetrate the underlying thrust fault that apparently raised the terrace (Fig. 2). This same terrace was drilled at Site 298 (Leg 31), located about $15 \mathrm{~km}$ to the southwest and slightly inboard (Fig. 1). Site 298 was only spot cored, however, and inadequate seismic resolution precludes precise correlation of the few cores recovered with major structures or with the undeformed section in the Nankai Trough.

The Nankai Trough marks the surface expression of the Shikoku subduction zone, characterized by relatively slow convergence and by a thick and young incoming sedimentary section. Estimates of convergence rates range from about $4 \mathrm{~cm} / \mathrm{yr}$. (Seno, 1977), derived from seismologic data, to about $2 \mathrm{~cm} / \mathrm{yr}$. (Ingle, Karig, et al., 1975), based on drilling and other geologic data. Results from Leg 87A provide additional geologic data in support of the lower rate (Karig, this volume). Trench sediments are $560 \mathrm{~m}$ thick at Site 582 (site chapter, Site 582, this volume), but increase to $1 \mathrm{~km}$ thick at the northern edge of the Nankai Trough and also thicken eastward. The underlying Shikoku Basin sediments are about $800 \mathrm{~m}$ thick, based on seismic reflection data, and have been compacted beneath the trench fill (site chapter, Site 582, this volume). The entire section is probably no older than early Miocene, based on extrapolation of results at Site 297 (Ingle, Karig, et al., 1975).

Trench-fill sediments at Site 582 are interbedded turbidites and hemipelagites (Fig. 3). Sand-rich intervals were apparently selectively washed away by drilling and are represented by zones of very poor recovery, judging from (1) drilling characteristics typical of sand, (2) traces of sand in some cores, and (3) good correlation of these zones with strong seismic reflectors. Sandy intervals apparently decrease in number downward in the section, but grain size does not vary systematically with depth. The trench sands and silts contain abundant volcanic and lithic fragments, heavy minerals, and some chert. The underlying Shikoku Basin hemipelagites differ from the trench fill in that they (1) lack coarse silt and sand layers, (2) lack graded beds with Chondrites traces, (3) contain abundant Zoophycos and Planolites traces, (4) contain abundant green laminations, (5) contain gray to green gray color alternations, and (6) contain nannofossil-rich intervals and pumice clasts isolated in a mudstone matrix. None of the Shikoku Basin section has a significant component of biogenic silica or carbonate, and none shows cementation.

The section drilled at Site 583 cannot be correlated in detail to that at Site 582 , but it is clearly analogous to the upper part of the trench-fill sequence and quite probably includes a thin section of slope sediment at the top (Fig. 3). A total of eight holes drilled at Site 583 penetrated the basal structural terrace at three locations that 


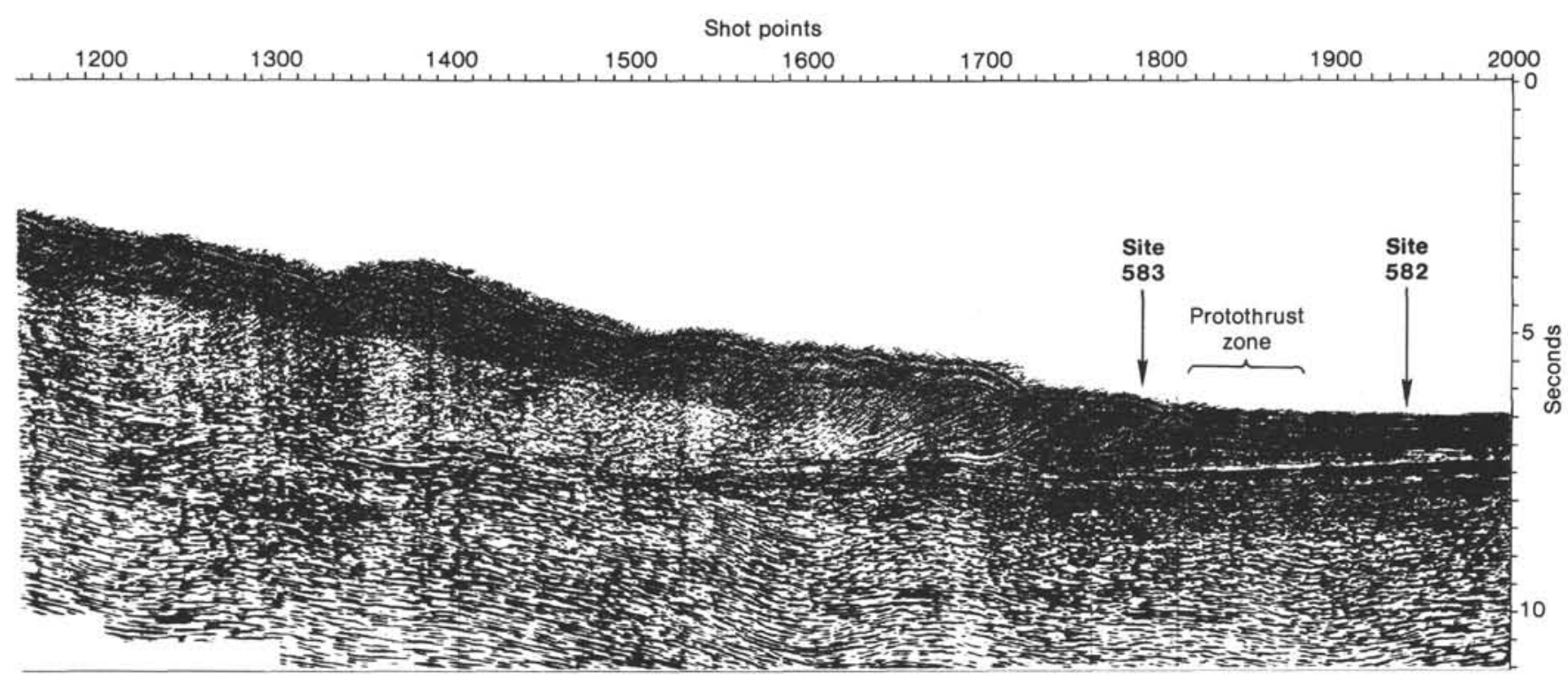

Figure 2. Seismic time section N55-3-1 at the base of the inner slope of the Nankai Trough, with locations of Sites 582 and 583.

span nearly $900 \mathrm{~m}$ across structural strike. Holes 583B, $583 \mathrm{C}$, and 583D were located near the toe of the basal thrust and were drilled to test for hydrocarbons that might have migrated up the fault. Holes $583,583 \mathrm{E}, 583 \mathrm{~F}$, and $583 \mathrm{G}$ constitute an attempt to penetrate the thrust fault at depth. Hole $583 \mathrm{~A}$ was offset to the north in order to sample the uppermost section that was missing or not resolved at the other sites. Holes 583, 583A, 583B, and $583 \mathrm{C}$ were drilled with hydraulic piston corer (HPC), whereas Holes 583D, 583E, 583F, and 583G were rotary drilled.

The cores recovered in these eight holes were not subdivided into separate lithologic units. As at Site 582, sandrich intervals decrease in abundance downhole, but not in grain size or apparent thickness. The results of logging part of Hole $583 \mathrm{~F}$ are consistent with the interpretation of intervals of poor recovery as sand rich and suggest an abundance of sand in the section, with some evidence of meter-scale graded beds or fining-upward sequences of thinner turbidites. Sand mineralogy is also similar to that at Site 582 .

However, correlation of the sections penetrated at the two sites is problematic. A lack of distinctive marker beds in the cores precludes a simple lithologic correlation. Offset of biostratigraphic markers and a structural reconstruction suggest over $150 \mathrm{~m}$ of stratigraphic offset along the thrust fault (Structural Geology section, site chapter, Site 583, this volume). A conflicting interpretation, based on seismic-reflection patterns, suggests only 40 to $50 \mathrm{~m}$ of stratigraphic offset (Seismic Correlation section, site chapter, Site 583, this volume).

Seismic reflection Profile N55-3-1, along which Sites 582 and 583 are located, illustrates the style of deformation in this area (Fig. 2). The major decollement is seen to selectively shear off sediments of the trench wedge as tabular thrust slices, which are added to the base of an imbricate stack. Each slice, bounded by clearly recognizable thrust faults, is wedge-shaped in section, reflecting both its original geometry and arcward-increasing internal thickening (Karig, this volume). Subsequent accretion tilts previously emplaced thrust slices and folds the upper thrust slice into hanging-wall anticlines. This and other profiles also show that the structure at Site 298 was misinterpreted. Instead of an overturned anticline (Moore and Karig, 1976), the section drilled represents an upright thrust slice.

\section{SITE 582}

Trench-fill and Shikoku Basin sediments and sedimentary rocks recovered at Site 582 are little deformed, as expected from their location seaward of the deformation front. Cores from Site 582, therefore, provide a valuable control site for comparison with cores from the landward slope of the Nankai Trough at Sites 298 and 583. In particular, the extent and styles of drilling deformation can be evaluated in the nearly undeformed section here and is apparently limited to readily identified features, such as swirled and bowed bedding in the upper cores, drilling laminations and biscuits marking horizons along which the core was spun by drilling, and open fractures of clearly artificial origin.

\section{Bedding}

Bedding dips from trench-fill sediments are very low (Fig. 4) and reflect primarily the deviation of the hole from vertical, which increases downhole to at least $8^{\circ}$ (site chapter, Site 582, this volume). A slight but sharp increase in dip was observed in the subjacent Shikoku Basin strata. Although the difference is less than $5^{\circ}$, close to the accuracy of our measurements, it probably reflects the downbowing of the Philippine Plate, as is also documented by the 2 to $3^{\circ}$ northerly dip of these strata on the seismic-reflection profile (site chapter, Site 582, this volume).

\section{Faults and Fissility}

The only pervasive structural fabric developed in most cores from Site 582 is a bedding-parallel fissility that be- 

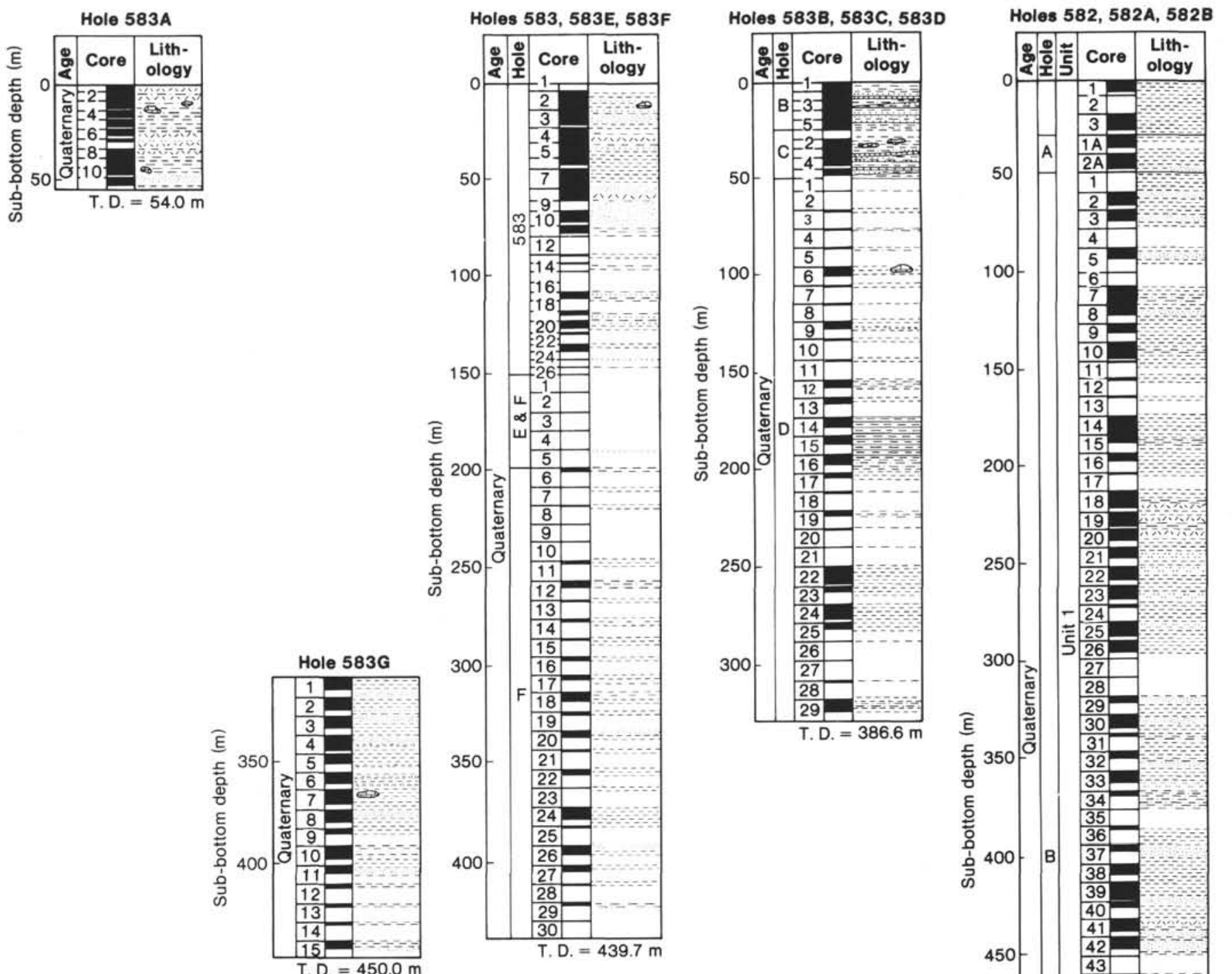
Landward

Hole 583A
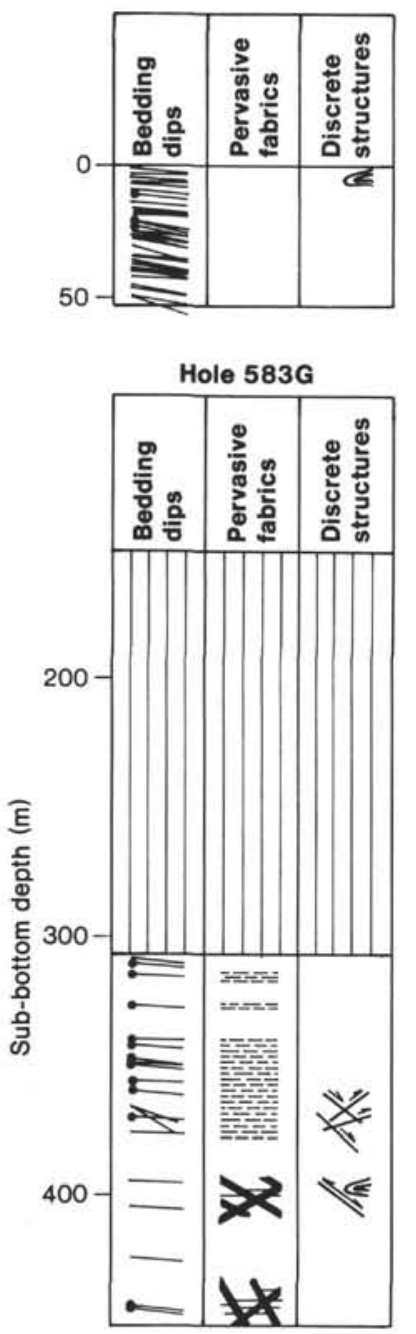

Holes 583E,

$583 \mathrm{~F}$

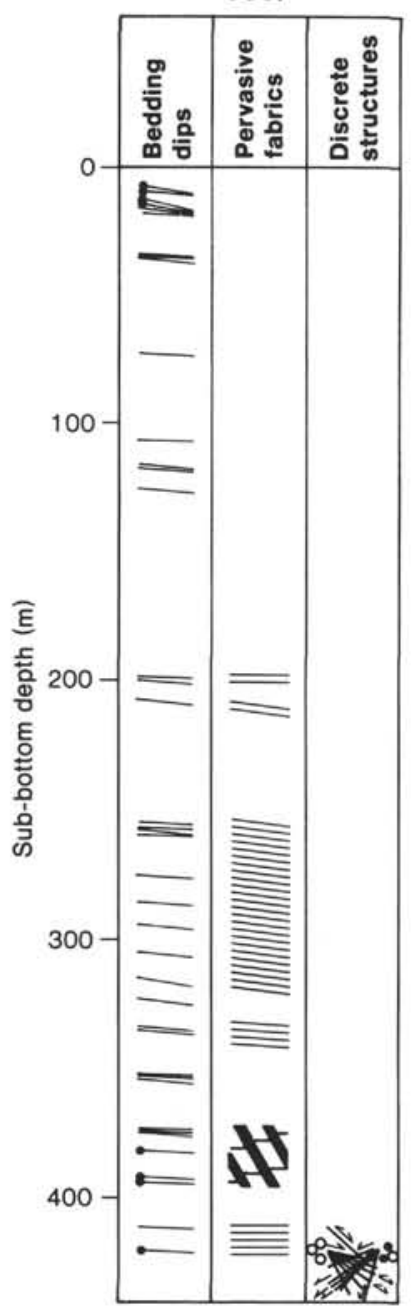

Holes 583B,

583C,583D

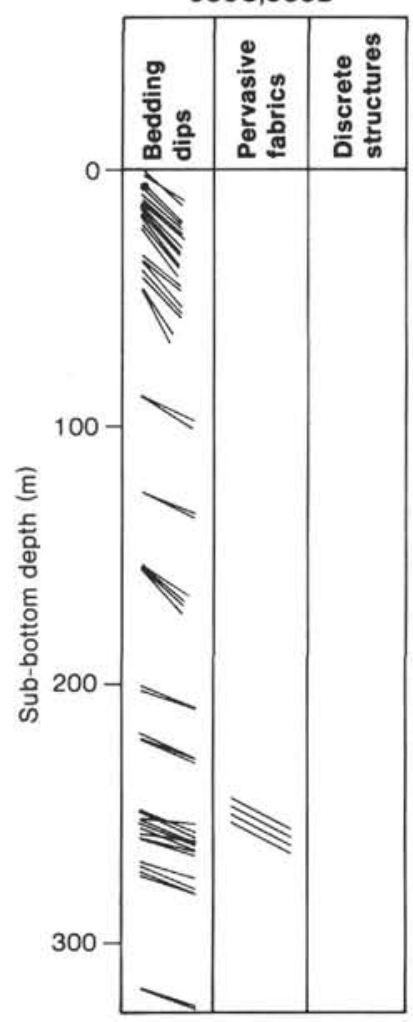

Seaward

Hole 582

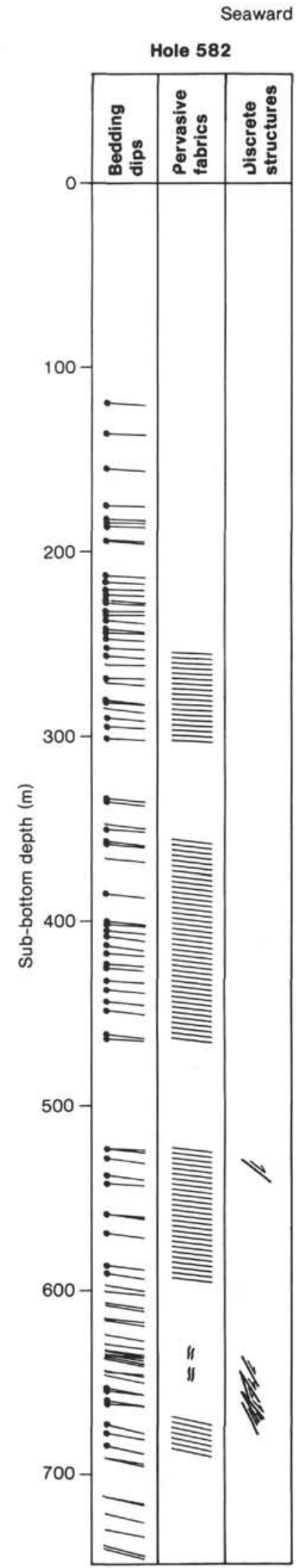

Bedding dips

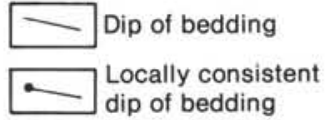

Discrete structures

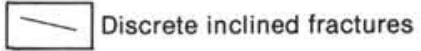

S Set of parallel fractures

Pervasive fabrics

Fissility

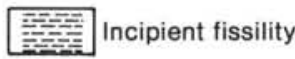

\& Vein structure

A Kinks

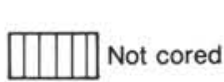

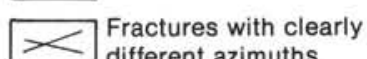

$>$ different azimuths

$\longrightarrow$ Normal fault

$\leftarrow$ Reverse fault

$\rightleftarrows$ Dip-slip fault

- Oblique-slip fault

- Strike-slip fault

« Minor fold
Figure 4. Graphic structural log depicting location, frequency, and orientation of bedding, penetrative fabrics, and discrete structures in cores from sites drilled in the Nankai Trough and inner slope, Leg 87A. Holes are arranged geographically, from landward at the left to seaward at the right. Lengths of affected intervals may be somewhat exaggerated for clear portrayal of features. 
comes discernible near a depth of $254 \mathrm{~m}$, at which point the core was split by circular saw rather than by wire. Fissility becomes stronger with depth and by $518 \mathrm{~m}$ subbottom approaches a true shaly fabric along which the mudstone splits into thin wafers. Fissility was probably produced by simple compaction caused by burial, accentuating a primary alignment of platy mineral grains. Intervals that are bioturbated have not developed fissility, presumably because biologic reworking destroyed the initial anisotropic fabric of the sediment.

Six healed faults were observed cutting the Shikoku Basin hemipelagites at 635 to $661 \mathrm{~m}$. These are dark shear zones several mm thick that cut the section at high angles $\left(52\right.$ to $\left.80^{\circ}\right)$ and are interpreted as normal faults on the basis of visible offset and drag features. One planar, open fracture at a slightly shallower depth $(518 \mathrm{~m})$ dips $39^{\circ}$ and is also interpreted as a normal fault on the basis of down-dip slickenlines and distinct steps on the polished fracture surfaces. These faults are most likely results of extension during flexure of the Philippine Plate as it enters the subduction zone (Ingle, Karig, et al., 1975; Ukawa, 1982). Brittle rupture along the normal faults was no doubt facilitated by reduced effective confining pressure resulting from presumed high pore pressures accompanying rapid deposition of the trench-fill sediments above (Bray and Karig, in prep.).

\section{Vein Structure}

Subvertical sets of mud-filled veins also cut the Shikoku Basin hemipelagites in the same interval as the healed normal faults, discernible sparsely and faintly between 634 and $644 \mathrm{~m}$. These veins range in appearance from solitary near-vertical dark surfaces to parallel sets or bands of nested veins, which are locally slightly sigmoidal in detail. Bedding is commonly offset across these veins, typically by $1 \mathrm{~mm}$ or less (Fig. $5 \mathrm{~A}$ ). Because the veins are perpendicular to bedding, the offset cannot be classified as either normal or reverse (Fig. 5B). The veins themselves, however, probably formed initially as extensional features. Although poorly developed, they are identical to the vein structure reported in previously drilled forearc areas (Arthur et al., 1980; Cowan, 1982) and apparently reflect horizontal extension (Cowan, 1982; Lundberg and Leggett, this volume). These veins may form in a manner similar to tension gashes, although the mud filling them is probably altered in situ sediment, rather than sediment that has migrated in to fill void spaces (R. Knipe, pers. comm., 1983). Thus, the term "vein" is somewhat misleading, despite the geometric and kinematic similarities between these mudfilled features and conventional veins (Lundberg and Leggett, this volume). Veins are dark zones in thin section (Fig. 5C), commonly with a slightly finer grain size than surrounding sediment. Insertion of a quartz quarter-wave plate show a preferred orientation of phyllosilicates within veins, subparallel to vein boundaries and thus at a high angle to the bedding-parallel fabric in the surrounding sediment (Fig. 5D).

Vein structure has previously been recognized only in DSDP sites drilled on inner trench slopes, and in limited regions onland, also from trench slope environments
(Ogawa, 1980). The presence of vein structure in cores from the Nankai Trough itself is therefore surprising. Their formation may be directly related to the associated normal faulting, or they may simply be another type of response of the sediment to the same deformational conditions (mild extension coupled with elevated pore pressures). Healed faults and veins were encountered in only one restricted interval at Site 582, but there are no obvious lithologic characteristics, such as grainsize variation, that might explain the localization of brittle deformation.

High pore pressure is expected in trench-slope sediment because of the rapid deposition of low-permeability sediments and the potential for tectonic loading by thrust faulting. Evidence of high fluid pressures has been found in the Japan Trench slope, where vein structure is abundantly developed (Arthur et al., 1980), and at the toe of the trench slope off Barbados, where it is weakly developed (Cowan et al., 1984). There is no evidence, however, that hydrofracturing (or the rapid and dynamic expulsion of fluids) is itself the principal cause of vein structure.

\section{SITE 583}

The eight holes drilled at Site 583 help define the structural geometry of the frontal thrust. This thrust is a bedding-plane step thrust, with a $30^{\circ}$ ramp that flattens at depth to join the main decollement (Fig. 6). Near the surface the thrust branches into two splays, and the shallowest extension of the thrust surfaces is seismically not well defined. At the nose of the frontal thrust, a slump deposit is apparently advancing ahead of the thrust sheet itself (Karig, this volume).

\section{Bedding and Seismic Reflectors}

Bedding dips in the section drilled at Holes 583B, 583C, and 583D (at the toe of the frontal thrust) are surprisingly steep at the surface and become consistently gentler at depth. The uppermost $50 \mathrm{~m}$ of interbedded hemipelagic mud and turbiditic sands, drilled by the HPC in Holes 583B and 583C, dip steeply and consistently at about $45^{\circ}$ (Fig. 4). Consistent dip directions within each piston core indicate a homoclinal dip, and the most reliable orientation data collected by Kuster device suggest that the dip is toward the south or south-southeast (site chapter, Site 583, this volume). Paleomagnetic declinations substantiate a southerly, or trenchward, dip. Deeper cores at this location, rotary drilled at Hole 583D, show shallower dips, generally 15 to $25^{\circ}$. The observed pattern of homoclinally steep dips over shallow dips suggests a structural break at some point between 50 and 80 $\mathrm{m}$, which we interpret as a hanging-wall imbrication, inferred from the reflection profile (Fig. 6). The steeply dipping uppermost section drilled at Holes 583B, 583C, and 583D is from the southern limb of a hanging-wall anticline, formed either by drag along the thrust fault, or as a fault-bend fold or a fault-propagation fold (Suppe, 1983). Most measured dips below this level are shallow to moderate, but markedly steeper dips ( 37 to $49^{\circ}$ ) in Core 583D-12 at 152.6 to $162.3 \mathrm{~m}$ (Fig. 4) document a second tilted interval. This deeper deformed zone has 

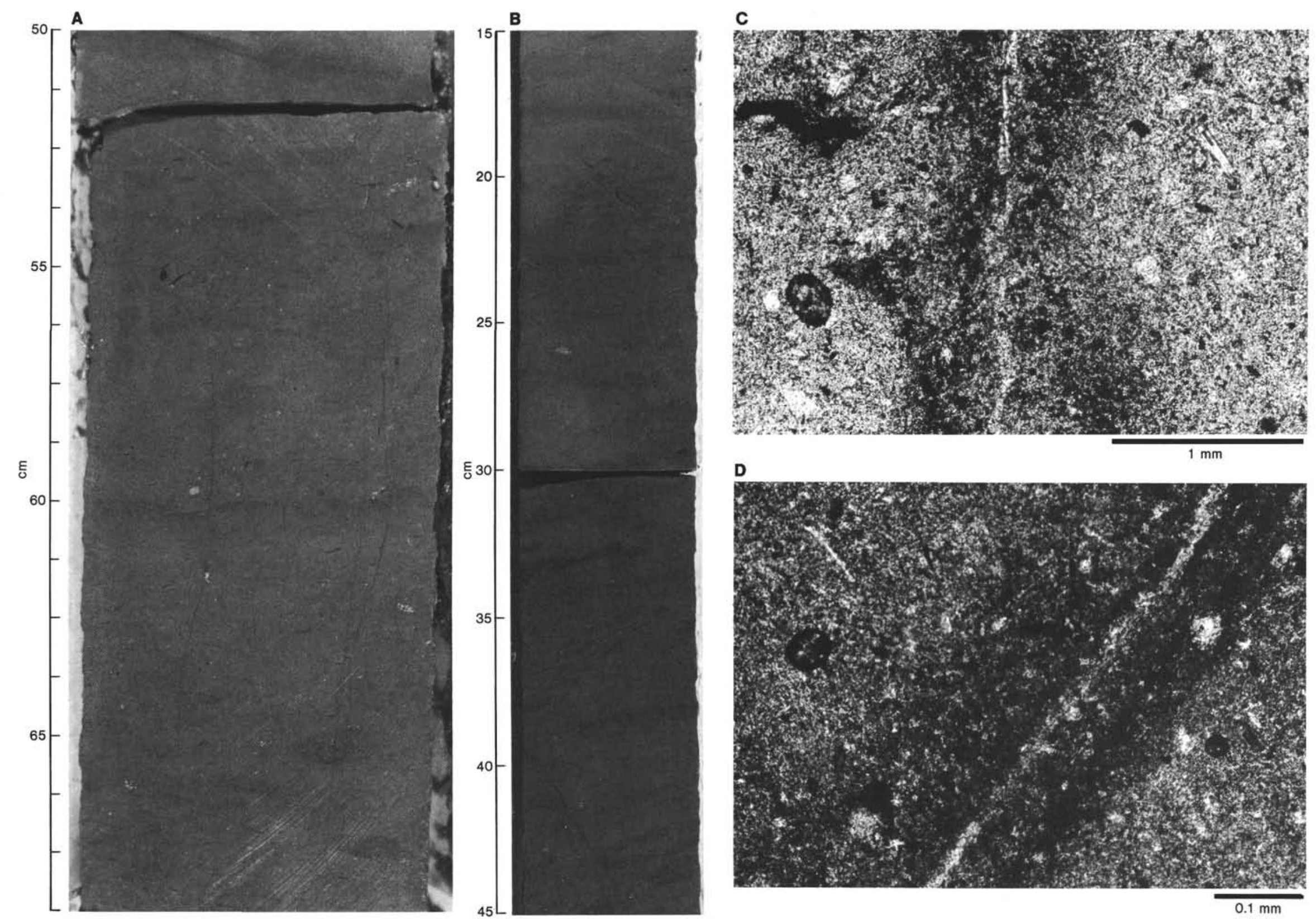

Figure 5. Vein structure in cores from Site 582 in the Nankai Trough. A. Subvertical set of poorly developed veins cut horizontal bedding at $582 \mathrm{~B}-62-4$, $50-65 \mathrm{~cm}$ (638 $\mathrm{m}$ sub-bottom). Minute displacements are discernible across the traces of the nearly planar surfaces. B. Clear offset of burrows across sediment-filled veins at 582B-62-2, 15-45 cm (635 m sub-bottom). The veins at 24 to $30 \mathrm{~cm}$ in this core were slabbed, impregnated, and thin-sectioned for the following photomicrographs (5C and 5D). C. Dark staining along selvages of individual vein from sample pictured in 5B. Plane light, section normal to bedding and veins. D. Preferred orientation of phyllosilicates within vein from sample pictured in 5B. Fabric within vein enhanced by crossed nicols and insertion of quartz plate. Section normal to bedding and veins. 

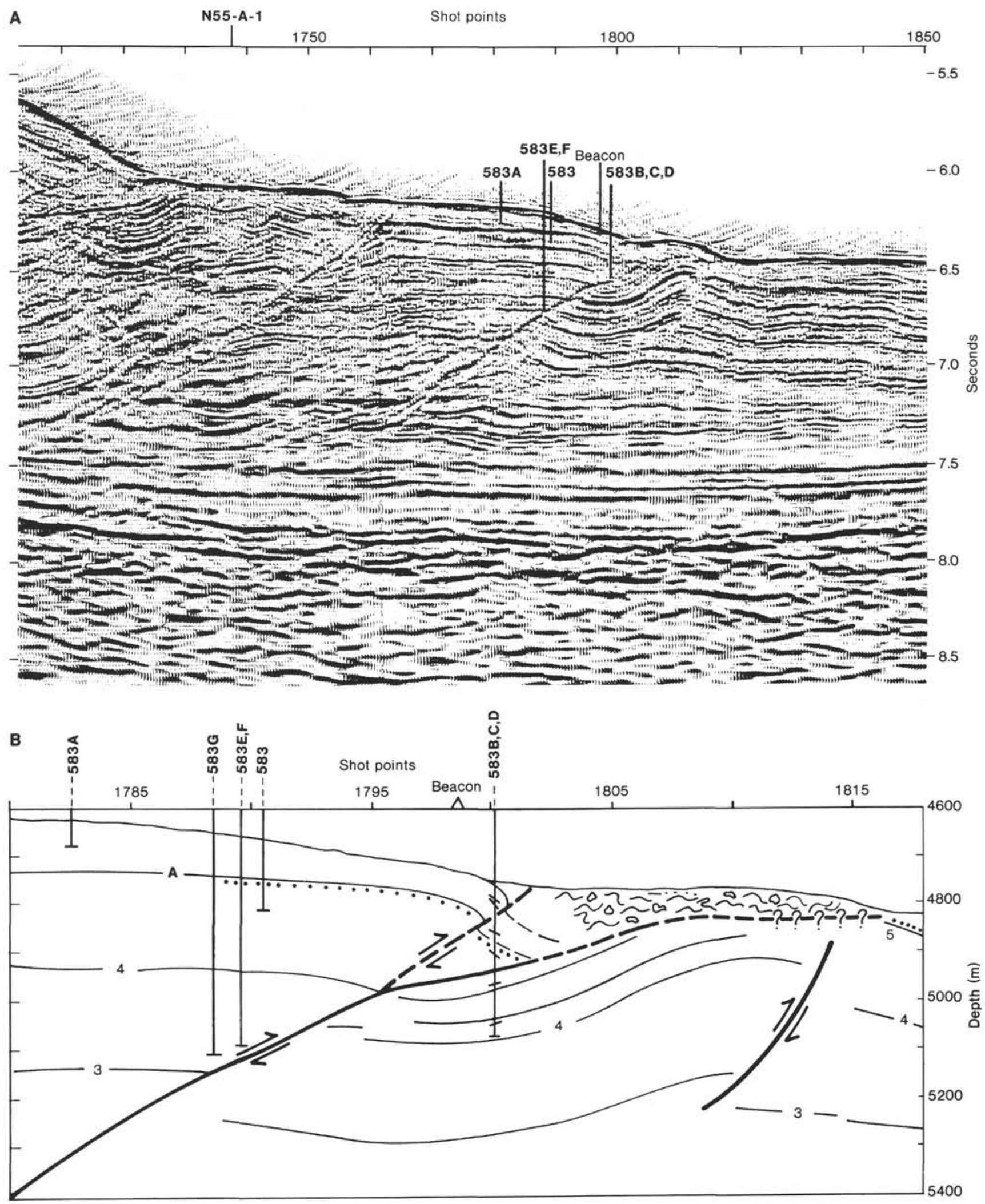

Figure 6. Large-scale structure at Site 583. A. Close up of seismic profile N55-3-1 at location of Site 583 (time section). B. Interpretive depth section across area drilled at Site 583. (From Karig, this volume.) 
probably been folded by drag along the lower splay of the thrust fault, which can be inferred from the reflection profile at about this depth (site chapter, Site 583, this volume). Bedding dips in the section between the two postulated thrust fault splays are moderate (22 to $34^{\circ}$ ), and a single paleomagnetic measurement suggests a southeasterly dip (site chapter, Site 583 , this volume).

Below the main displacement surface of the thrust fault, bedding dips are approximately $20^{\circ}$ (core averages range from 16.5 to $22^{\circ}$ ). Sparse paleomagnetic measurements suggest a northwesterly dip for this deeper section (site chapter, Site 583, this volume). This deeper section likely represents the southern limb of a syncline defined seismically in the foot wall (Fig. 6), although the reflection profile suggests that we penetrated the nearly horizontal beds in the trough of the fold.

None of the folding evident in Holes 583B, 583C, and $583 \mathrm{D}$ is present in the other holes drilled at Site 583, north of the ramp corner of the frontal thrust. Bedding planes are nearly horizontal throughout most of Holes $583,583 \mathrm{E}, 583 \mathrm{~F}$, and $583 \mathrm{G}$, all of which were drilled at the same location. An upper 45-m zone of soft sediment shows only bedding surfaces that have been bowed strongly by piston coring (Hole 583, Fig. 4). The only other bedding dips here that are not virtually horizontal are steep dips $\left(48\right.$ to $\left.62^{\circ}\right)$ found in a short interval in Core 583G-10, sandwiched between intervals with consistently shallow dips and most likely produced by slump folding. The main objective in drilling this location, to penetrate the frontal thrust fault at depth, was apparently not achieved. Analysis of the reflection profile suggests, however, that Holes $583 \mathrm{~F}$ and $583 \mathrm{G}$ probably were cored to within a few tens of meters of the thrust zone. The nearly horizontal orientation of bedding dips in the cores recovered at Holes $583 \mathrm{~F}$ and $583 \mathrm{G}$ indicate that very little folding is associated with the thrust at this location. The folding at Holes 583B, 583C, and 583D, the lack of folding at Holes 583, 583E, 583F, and 583G, and the reflection profile define a bedding-plane step-thrust that flattens near the surface, producing a roughly triangular prism that has been isolated by a steeper fault splay, above which the hanging wall is draped over and dragged into an anticline.

\section{Faults and Fractures}

Open and healed fractures cut the cored sediment in Holes $583 \mathrm{~F}$ and $583 \mathrm{G}$ below about $350 \mathrm{~m}$. The relatively few fractures that appear to be natural features exhibit mainly dip-slip striations on smooth, moderately polished surfaces. A major set of these faults dips approximately $40^{\circ}$, and locally a minor set of apparently conjugate faults dips 20 to $30^{\circ}$ in the opposite direction. Distinct steps run across the fracture surfaces horizontally, consistently face downdip, and mark the intersection of bedding and bedding-parallel fissility with the fracture surfaces. These steps appear at first to imply normalfault offset, but is shown to be incorrect by the few offsets visible on split core surfaces, which show the fractures to be reverse faults. This sense of displacement is further confirmed by the shallow dip of the acute bisector of the two sets of faults $\left(5\right.$ to $\left.10^{\circ}\right)$, assuming that they are conjugate. Paleomagnetic measurements indicate that the nearly horizontal intersection of the two sets of faults is roughly parallel to the Nankai Trough (site chapter, Site 583, this volume), suggesting that to a first approximation the direction of maximum compressive stress parallels the convergence direction, as expected. Along these reverse faults, displacements, where they can be determined, are small, on the order of several $\mathrm{mm}$ to several $\mathrm{cm}$.

In clay-rich strata cored at depth at Site 583, fissility is commonly developed parallel to bedding, Fissility is marked by fabrics ranging from very planar laminations to a subhorizontal parting. This fabric is defined by a system of anastomosing cracks that are spaced $1 \mathrm{~mm}$ or less apart and that isolate lenses of clay up to $1 \mathrm{~cm}$ long. Fissility is developed locally below $211 \mathrm{~m}$ in Hole 583D and below $199 \mathrm{~m}$ in Hole 583F.

\section{Kinks}

The most intriguing structures in the deeper cores from Holes $583 \mathrm{~F}$ and $583 \mathrm{G}$ are dark, inclined, planar zones that kink sedimentary layering. These kinks are 2 to $5 \mathrm{~mm}$ across and have a very regular geometry. They are extremely planar and occur in parallel sets, inclined typically about $60^{\circ}$ to virtually horizontal bedding (Fig. 7A). Several cores also exhibit conjugate kinks, with two sets that dip in opposite directions, one set developed more strongly than the other (Fig. 7B). An internal fabric is discernible in some kinks (Fig. 7C). This fabric is also very regular, with a consistent asymmetry defined by nested dark surfaces, which are most likely individual slip surfaces. These surfaces are slightly curviplanar or sigmoidal. An individual strand is typically convex outward where it bounds the kink on one side, becomes planar as it extends within and across the kink, and in flects to finally bound the kink on the other side of the kink, convex outward once again (Fig. 7C). Each strand terminates against neighboring strands at both ends and is several $\mathrm{cm}$ long. These kinks are movement surfaces. Kinks rotate primary layering, fissility, and conjugate kinks consistently in the sense of a reverse fault (Fig. 7C).

In thin section, individual strands are marked by zones of realignment of phyllosilicates (Fig. 8). Phyllosilicates appear to be more abundant and considerably better oriented within kinks than in the surrounding sediment, suggesting minor preferential dissolution in addition to the clearly mechanical bending seen at zone boundaries. Mineral grains have been rotated from an orientation parallel to bedding to one inclined about $60^{\circ}$, passing through an orientation perpendicular to the kink itself.

The kinks have sharp boundaries in thin section, and phyllosilicates are bent strongly into the dominant orientation at kink boundaries, rather than folding smoothly around a broad fold axis. Phyllosilicates in all strands in a given thin section are oriented subparallel, suggesting some natural limit to rotation without rupture. Kinks apparently grow by broadening of individual strands, rather than by the formation of additional slip surfaces at kink boundaries. Some kinks are slightly darker than surrounding sediment in thin section as well as macroscopically, perhaps because of slightly finer grain size. 
A

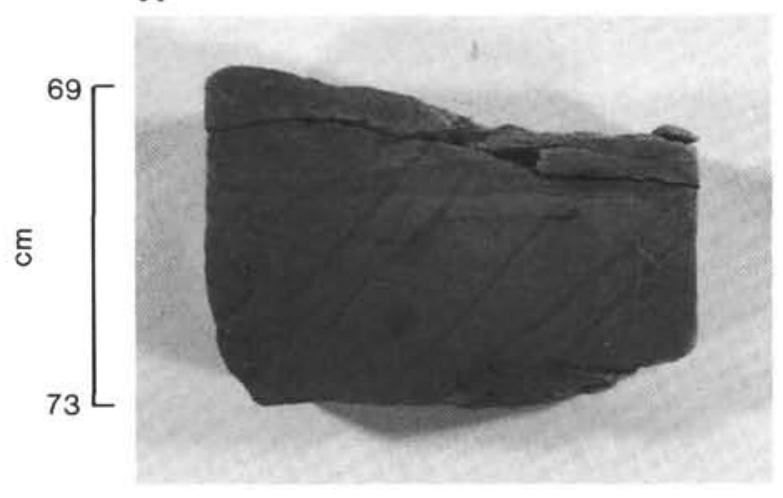

B
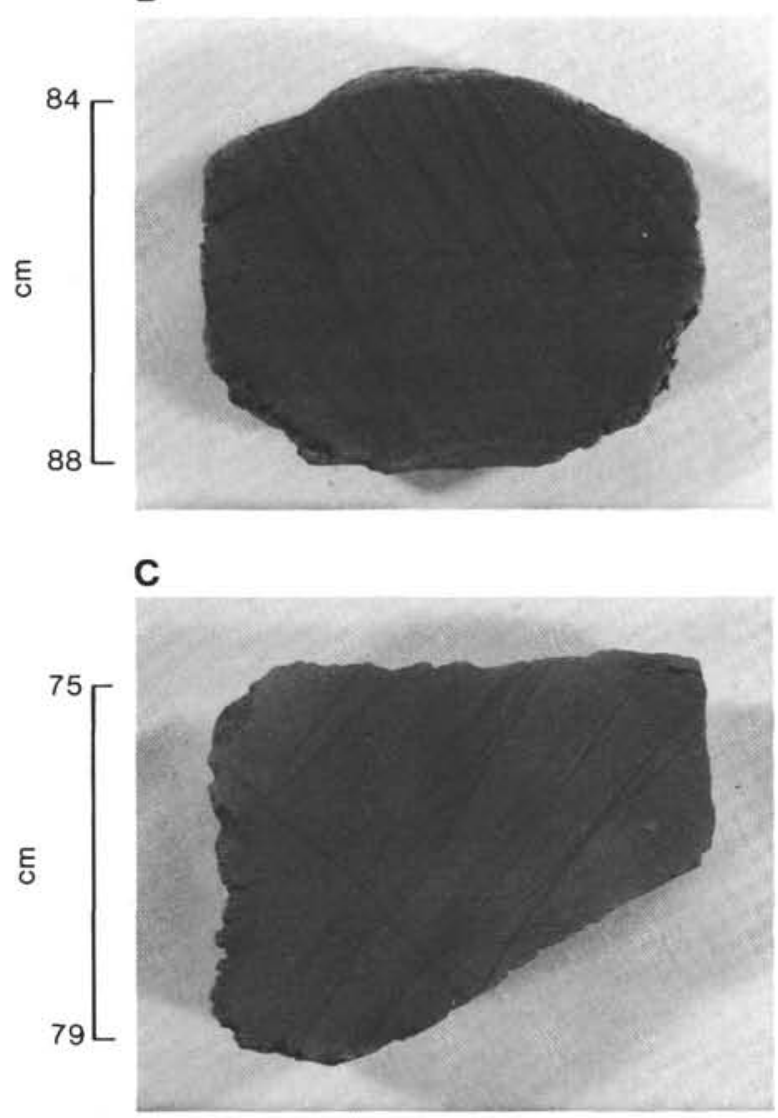

Figure 7. Kinks at Site 583 at the base of inner slope. A. Sample 583F$25-1,69-73 \mathrm{~cm}$ (382.5 m sub-bottom). Parallel set of kinks, with $64^{\circ}$ true dip, cross-cut bedding that dips $3^{\circ}$. Kinks affect bedding only subtly here. B. Sample $583 \mathrm{~F}-24-3,84-88 \mathrm{~cm}(375 \mathrm{~m}$ sub-bottom). Apparently conjugate sets of kinks, one with very dense spacing. Bedding and bedding-parallel fissility virtually horizontal. Subtle internal fabric composed of regularly nested dark strands, apparently surfaces of minute slip. Photomicrographs pictured in Figure 8 are from this sample. C. Sample 583G-15-1, 75-79 $\mathrm{cm}$ (443 m sub-bottom). Internal fabric well displayed in broad kinks that clearly rotate earlier formed, opposite-dipping kink in the sense of a reverse fault.

Kinks represent horizontal shortening, accomplished as minute differential displacement along myriad parallel movement zones. They are pervasive on a scale of several centimeters to a few tens of centimeters and are developed consistently in cores below a depth of $350 \mathrm{~m}$ (e.g., at Site 583 in both holes drilled to this depth and at Site 298 [Lundberg, unpublished data]). Thin kinks $(<1 \mathrm{~mm})$ are generally densely spaced, several per centimeter, whereas broader kinks (up to $5 \mathrm{~mm}$ ) are spaced 2 to 20 or $30 \mathrm{~cm}$ apart. We have calculated the amount of strain recorded in a number of intervals that display details of kinks clearly, assuming a passive rotation of $45^{\circ}$ within the kinks and no dissolution along them. The shortening represented ranges from 3 to $10 \%$, and $5 \%$ appears to be a reasonable estimate for the overall contribution of kinks to horizontal shortening.

Kinks offer an unusual opportunity to correlate corescale structures with large features seen on reflection profiles. The $60^{\circ}$ dip of kinks in cores from Site 583 is inconsistent with structures seen seismically at the drill site, in particular the low-angle $\left(30^{\circ}\right.$ and shallower) thrust faults. This orientation is consistent, however, with highangle seismic discontinuities in the "protothrust" zone, immediately south of the frontal thrust fault (Fig. 2). These discontinuities, which may be faults or sharp flexures, dip $60^{\circ}$ to the north and offset trench sediments with consistently reverse displacement. We interpret the kinks at Site 583 to have formed in this environment, when the drilled section was in a setting analogous to that of the protothrust zone. We view the system of highangle discontinuities in the protothrust zone as largescale kinks that crenulate the incoming sedimentary section, which clearly has a strong planar anisotropy parallel to the direction of maximum compressive stress. Thus, the initial subduction-generated deformation of these deposits appears to be layer-parallel compression.

\section{SUMMARY AND CONCLUSIONS}

Small-scale structural features in cores from Site 582, located in the Nankai Trough, include healed normal faults, vein structure, and bedding-parallel fissility. Cores from Site 583, drilled at the toe of the landward slope, contain intervals of steep, homoclinal bedding dips and exhibit healed and open faults and fractures, kink bands, and bedding-parallel fissility.

Normal faults and weakly developed vein structure in cores from Site 582, located in the trench floor, reflect mild extension during flexure of the incoming Philippine Plate. Vein structure has heretofore been described only from trench slope environments. Both normal faults and vein structure are found only in a thin interval (634 to $661 \mathrm{~m}$ sub-bottom) in Shikoku Basin hemipelagites penetrated at the base of the hole. Brittle rupture in these low-permeability sediments was doubtless aided by high pore pressure, presumably caused by rapid deposition of the thick overlying trench deposits (Bray and Karig, in prep.).

Bedding dips are steeper than expected in cores from Holes 583B, 583C, and 583D drilled through the nose of the frontal thrust sheet, presently being uplifted into the base of the trench slope. Measured dips define (1) a steeply dipping homocline between 0 and $60 \mathrm{~m}$ that represents the southern limb of a hanging-wall anticline, (2) a moderately inclined section between 60 and $160 \mathrm{~m}$ that was probably folded by drag along one or both bounding thrust fault splays, and (3) a shallowly inclined sec- 

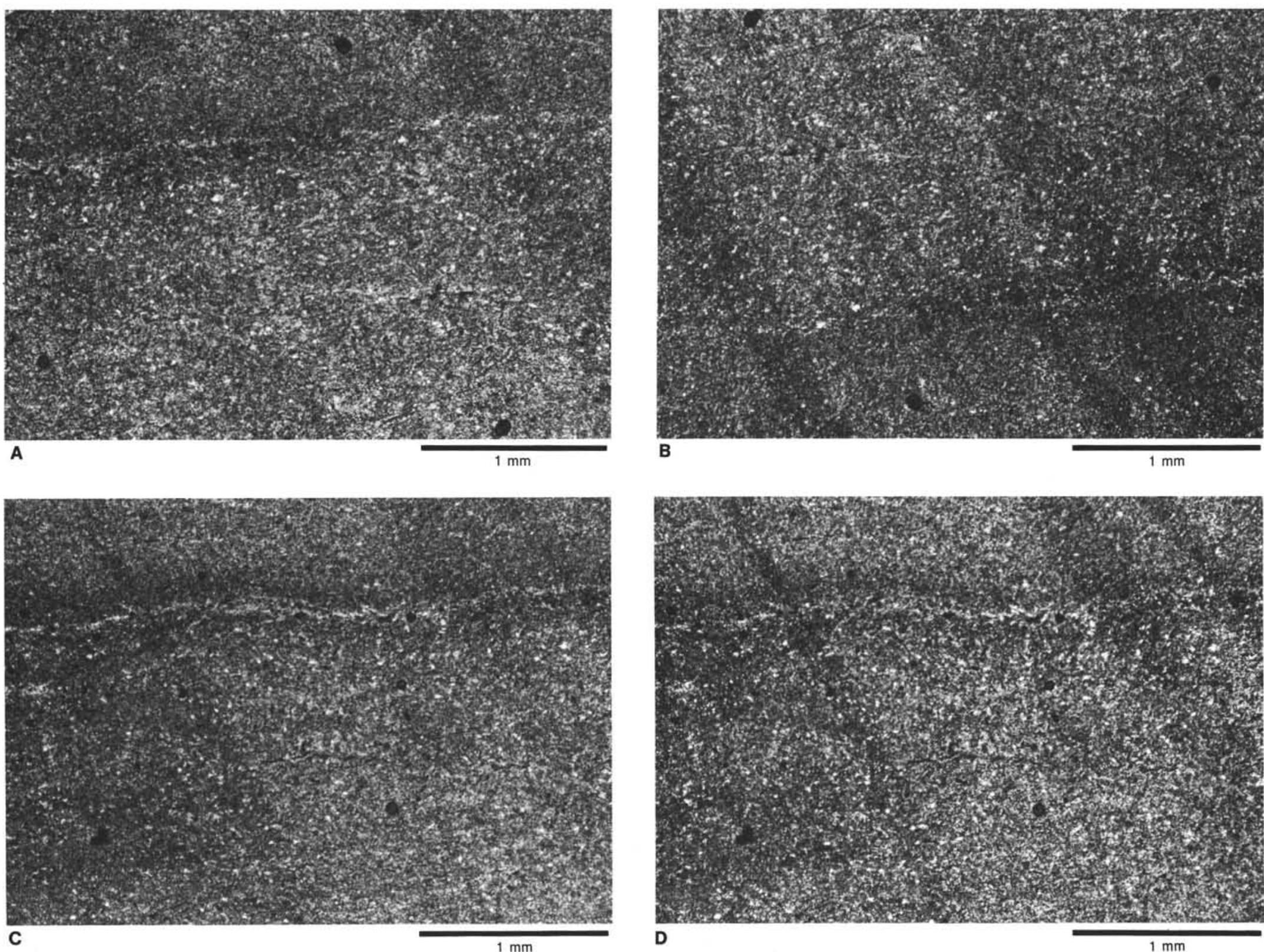

Figure 8 . Bedding rotated by kinks at Site 583 , Sample $583 \mathrm{~F}-24-3,84-88 \mathrm{~cm}$. Near-horizontal, slightly wavy bands are bedding traces. A. Microscopically, kinks locally show up as dark zones in plane light; rotation of bedding is clear on this scale. Section normal to bedding and kinks. Up is toward top of photo. B. Same view as A, but with partially crossed nicols and a quartz plate inserted to enhance kinks. C. Another example of rotation of bedding, like that of a reverse fault, in the same samp
Up is toward top of photo. D. Same field of view as C, but with nicols partly crossed and quartz plate inserted to enhance kinks. 
tion below $160 \mathrm{~m}$ that apparently occupies the seaward flank of a broad, open syncline in the foot wall.

Kinematics of the relatively small number of faults in two deep holes that terminated just above this thrust at depth, in Holes $583 \mathrm{~F}$ and $583 \mathrm{G}$, indicate a shallow-dipping direction of maximum compressive stress $\left(5\right.$ to $\left.10^{\circ}\right)$, which paleomagnetic measurements suggest is normal to the trend of the Nankai Trough. Kink bands several millimeters thick in these same intervals also indicate horizontal shortening along high-angle movement zones. A proposed correlation of these kinks with a seismically defined system of high-angle discontinuities suggests formation of the kinks in the protothrust zone as the earliest deformational structure associated with accretion. Both core-scale structural features and large-scale structures interpreted on the basis of drilling results and the reflection profile represent horizontal shortening perpendicular to the trench.

\section{ACKNOWLEDGMENTS}

We thank our fellow shipboard participants on Leg 87, as well as M. A. Arthur and R. J. Knipe, for helpful discussions, and E. C. Beutner and J. C. Moore for critical reviews of the manuscript. This work was funded in part by National Science Foundation Grant OCE 81-10394 to J. C. Moore. Finally, we thank Gene Gonzales at University of California at Santa Cruz for his patience and unsurpassed skill in preparation of thin sections from the partially lithified muds.

\section{REFERENCES}

Arthur, M. A., Carson, B., and von Huene, R., 1980. Initial tectonic deformation of hemipelagic sediment at the leading edge of the Japan convergent margin. In Scientific Party, Init. Repts. DSDP, 56, 57, Pt. 1: Washington (U.S. Govt. Printing Office), 569-614.

Bray, C., and Karig, D. E., in prep. Dewatering and extensional deformation of the Shikoku Basin hemipelagic sediments in the Nankai Trough.

Cowan, D. S., 1974. Deformation and metamorphism of the Franciscan subduction zone complex northwest of Pacheco Pass, California. Geol. Soc. Am. Bull., 85:1623-1634.

1978. Origin of blueschist-bearing chaotic rocks in the Franciscan Complex, San Simeon, California. Geol. Soc. Am. Bull., 89:1419-1423.

1982. Origin of "vein structure" in slope sediments on the inner slope of the Middle America Trench off Guatemala. In Aubouin, J., von Huene, R., et al., Init. Repts. DSDP, 67: Washington (U.S. Govt. Printing Office), 645-650.

Cowan, D. S., Moore, J. C., Roeske, S. M., Lundberg, N., and Lucas, S. E., 1984. Structural features at the deformation front of the Barbados Ridge Complex, Deep Sea Drilling Project Leg 78A. In Biju-Duval, B., Moore, J. C., et al., Init. Repts. DSDP, 78A: Washington (U.S. Govt. Printing Office), 535-548.

Dengo, C. A., 1982. A structural analysis of cores from the Leg 67 transect across the Middle America Trench-offshore Guatemala. In Aubouin, J., von Huene, R., et al., Init. Repts. DSDP, 67: Washington (U.S. Govt. Printing Office), 651-666.

Dickinson, W. R., and Seely, D. R., 1979. Structure and stratigraphy of forearc regions. Am. Assoc. Pet. Geol. Bull., 63:2-31.

Draper, G., 1978. Coaxial pure shear in Jamaican blueschists and deformation associated with subduction. Nature, 276:735-736.

Elliott, D., 1976. The motion of thrust sheets. J. Geophys. Res., 81B: 949-963.

Hsü, K., J., 1974. Melanges and their distinction from olistostromes. In Dott, R. H., Jr., and Shaver, R. H. (Eds.), Modern and Ancient Geosynclinal Sedimentation: Tulsa, Oklahoma (Society of Economic Paleontologists and Mineralogists), Spec. Publ., 19:321-333.
Hussong, D. M., and Uyeda, S., 1982. Tectonic processes and the history of the Mariana Arc: a synthesis of the results of Deep Sea Drilling Project Leg 60. In Hussong, D. M., Uyeda, S., et al., Init. Repts. DSDP, 60: Washington (U.S. Govt. Printing Office). 909929.

Ingle, J. C., Karig, D. E., et al., 1975. Site 297. In Karig, D. E., Ingle, J. C., et al., Init. Repts. DSDP, 31: Washington (U.S. Govt. Printing Office), 275-316.

Karig, D. E., 1974. Evolution of arc systems in the western Pacific. Ann. Rev. Earth Planet. Sci., 2:51-75.

Karig, D. E., and Sharman, G. F., III, 1975. Subduction and accretion in trenches. Geol. Soc. Am. Bull., 86:377-389.

Leggett, J. K., McKerrow, W. S., and Casey, D. M., 1982. The anatomy of a lower Palaeozoic accretionary forearc: the Southern Uplands of Scotland. In Leggett, J. K. (Ed.), Trench-Forearc Geology. Geol. Soc. London, Spec. Publ., 10:495-520.

Lundberg, N., and Moore, J. C., 1982. Structural features of the Middle America Trench slope off southern Mexico, Deep Sea Drilling Project Leg 66. In Watkins, J. S., Moore, J. C., et al., Init. Repts. DSDP, 66: Washington (U.S. Govt. Printing Office), 793-805.

Maxwell, J. C., 1974. Anatomy of an orogen. Geol. Soc. Am. Bull., 85:1196-1204.

Moore, G. F., and Karig, D. E., 1980. Structural geology of Nias Island, Indonesia: implications for subduction zone tectonics. $\mathrm{Am}$. J. Sci., 280:193-223.

Moore, J. C., Biju-Duval, B., and Shipboard Scientific Party, 1982. Offscraping and underthrusting of sediment at the deformation front of the Barbados Ridge: Deep Sea Drilling Project Leg 78A. Geol. Soc. Am. Bull., 93:1065-1077.

Moore, J. C., and Karig, D. E., 1976. Sedimentology, structural geology, and tectonics of the Shikoku subduction zone, southwest Japan. Geol. Soc. Am. Bull., 87:1259-1268.

Moore, J. C., Watkins, J. S., Shipley, T. S., McMillen, K. J., Bachman, S. B., and Lundberg, N., 1982. Geology and tectonic evolution of a juvenile accretionary terrane along a truncated convergent margin: synthesis of results from Leg 66 of the Deep Sea Drilling Project, southern Mexico. Geol. Soc. Am. Bull., 93: 847-861.

Nasu, N., Tomoda, Y., Kobayashi, K., Kagami, H., Uyeda, S., et al., 1982. Multi-channel Seismic Reflection Data Across Nankai Trough: Tokyo (Ocean Research Institute, University of Tokyo), IPOD-Japan Basic Data Series, No. 4.

Ogawa, Y., 1980. Beard-like veinlet structure as fracture cleavage in the Neogene siltstone in the Miura and Boso Peninsulas, central Japan. Sci. Rep. Dep. Geol. Kyushu Univ., 13:321-327.

Quinquis, H., Audren, C., Brun, J. P., and Cobbold, P. R., 1978. Intense progressive shear in Ile de Groix blueschists and compatibility with subduction or obduction. Nature, 273:43-45.

Schweller, W. J., and Kulm, L. D., 1978. Extensional rupture of oceanic crust in the Chile Trench. Mar. Geol., 28:271-291.

Seely, D. R., Vail, P. R., and Walton, G. G., 1974. Trench slope model, In Burk, C. A., and Drake, C. L. (Eds.), The Geology of Continental Margins: New York (Springer-Verlag), pp. 249-260.

Seely, D. R., 1977. The significance of landward vergence and oblique structural trends on trench inner slopes. In Talwani, M., Pitman, W. C., III (Eds.), Island Arcs, Deep Sea Trench and Back-Arc Basins: Washington (Am. Geophys. Union), Maurice Ewing Series, 1:187-198.

Seno, T., 1977. The instantaneous rotation vector of the Philippine Sea plate relative to the Eurasian plate. Tectonophysics, 42: 209-226.

Smith, G. W., Howell, D. G., and Ingersoll, R. V., 1979. Late Cretaceous trench-slope basins of central California. Geology, 7: 303-306.

Suppe, J., 1983. Fault-bend folding. Am. J. Sci., 283:684-721.

Ukawa, M., 1982. Lateral stretching of the Philippine Sea plate subducting along the Nankai-Suruga Trough. Tectonics, 1:543-571.

Date of Initial Receipt: 12 January 1984

Date of Acceptance: 30 November 1984 